\title{
Concordia y discordia en el Renacimiento: el pensamiento sobre la guerra en la primera mitad del siglo XVI ${ }^{1}$
}

\section{Concord and discord in the Renaissance: thinking about the war in the first half of the sixteenth century}

\author{
Francisco Castilla Urbano ${ }^{2}$ \\ Universidad de Alcalá (España)
}

Recibido: 09-06-14

Aprobado: 02-07-14

\section{Resumen}

La guerra tiene una presencia permanente en el Renacimiento no sólo como una realidad que afecta a todos los pueblos sino como objeto de reflexión. Este artículo se ocupa de cuatro autores representativos de otras tantas tendencias de la primera mitad del siglo XVI. Todos ellos se ocuparon de pensar en la guerra, pero lo hicieron desde perspectivas que van de la oposición a la misma hasta su consideración como instrumento imprescindible de las relaciones de poder. Son los siguientes: el humanismo cristiano (Erasmo), la escolástica española (Vitoria), el protestantismo luterano y el humanismo cívico (Maquiavelo).

Palabras-clave: guerra, Erasmo, Francisco de Vitoria, Lutero, Maquiavelo.

\footnotetext{
${ }^{1}$ Este artículo se ha realizado en el marco del proyecto de investigación "Legitimación del poder político en el pensamiento medieval" (MICINN FFI 2010-15582).

2 (francisco.castilla@uah.es). Francisco Castilla Urbano (francisco.castilla@uah.es) es profesor Titular de Filosofía y Director del Departamento de Historia y Filosofía de la Universidad de Alcalá. Sus investigaciones se centran en la metodología de la historia de las ciencias sociales (El análisis social de Julio Caro Baroja: empirismo y subjetividad, 2002), y en el pensamiento moderno, donde se sitúan sus libros El pensamiento de Francisco de Vitoria. Filosofía politica e indio americano (1992); Juan Ginés de Sepúlveda (1490-1573) (2000), la edición del Diálogo llamado Demócrates (2012), de este último autor, y El pensamiento de Juan Ginés de Sepúlveda: vida activa, humanismo y guerra en el Renacimiento (2013).
} 


\begin{abstract}
War has a permanent presence in the Renaissance not only as a reality that affects all people but as an object of reflection. This article looks at four representative authors of many other trends from the first half of the sixteenth century. They catered to think about the war, but did so from perspectives ranging from opposition to the same consideration as essential to the power relations instrument. They are: Christian humanism (Erasmus), the Spanish scholastics (Vitoria), Lutheran Protestantism and civic humanism (Machiavelli).
\end{abstract}

Key-words: war, Erasmus, Francisco de Vitoria, Luther, Machiavelli.

\title{
1. Introducción
}

La diversidad filosófica característica del Renacimiento también se manifiesta a propósito de las ideas sobre la guerra. Desde el pacifismo que ve en la guerra el principal obstáculo para la felicidad de la humanidad, hasta la confianza en la misma como método de resolución de conflictos, las posturas ante la guerra son tan variadas como los mismos pensadores que las sustentan. $\mathrm{Ni}$ siquiera sirven para dar cuenta adecuada de esas diferencias las distinciones que suelen hacerse entre humanistas y escolásticos, pues no sólo hay otros grupos representativos, sino que incluso las afinidades ideológicas, formativas o sociológicas generales no excluyen importantes matices que no conviene ignorar si se pretende dar una noción lo más precisa posible de las actitudes renacentistas ante la guerra.

Por lo anterior y por evidentes razones de espacio, este estudio se centrará, más que en la totalidad del Renacimiento, en el siglo XVI y, dentro de éste, no irá más allá de 1546, año de la muerte de Martín Lutero y de Francisco de Vitoria, los últimos en fallecer de los autores aquí vistos. Aunque de cualquier opción de las aquí estudiadas se pueden señalar antecedentes antiguos o medievales, en casos como la teoría de la guerra justa son más fácilmente localizables ${ }^{3}$, mientras que otras alternativas, como la representada por Maquiavelo, sin dejar de situarse dentro de una tradición, suponen en mayor medida una revolución. Todas ellas son, no obstante, productos típicos del Renacimiento, con importantes dosis de innovación respecto a los siglos anteriores. En cualquier caso, el espacio disponible no nos permite entrar en antecedentes, y tampoco iremos más allá de una breve mención de las continuidades que tales teorías hayan podido tener a partir de la segunda mitad del siglo. La exposición se dividirá en cuatro autores representativos de otras tantas tendencias y que marcan una graduación

\footnotetext{
${ }^{3}$ F. H. Russell, The Just War in the Middle Ages, Cambridge University Press, 1975.
} 
de mayor a menor oposición a la guerra: el humanismo cristiano (Erasmo), la escolástica española (Vitoria), el protestantismo luterano y el humanismo cívico (Maquiavelo). Sería posible, sin duda, incluir otros nombres en lugar de los citados, y más deseable todavía sería añadir algunos casos más, así como marcar la evolución de las ideas sobre la guerra en sus seguidores y afines de la segunda mitad del XVI en adelante, pero tendrá que quedar para un empeño posterior.

\section{El humanismo cristiano ante la guerra}

El representante más distinguido del humanismo cristiano en el primer tercio del siglo XVI es, sin duda, Erasmo de Rotterdam. Su actitud de firme oposición a la guerra no es la única que se va a dar en este período ${ }^{4}$, pero, dada la importancia de su figura y pensamiento, sí va a ser de las más características e influyentes entre los estratos intelectuales y de gobierno de Europa.

Aunque nunca renuncia a utilizar argumentos naturalistas ${ }^{5}$ o sociales $^{6}$, el rechazo de Erasmo a la guerra tiene una raíz religiosa ${ }^{7}$. Son numerosos los textos bíblicos a los que una y otra vez se remite el humanista para dejar constancia de la dificultad de conciliar la práctica de la religión verdadera y la dedicación a la guerra. Unos textos que no necesitan de ningún añadido porque transmiten perfectamente su mensaje de amor. Por eso se rebela Erasmo contra quienes impregnan ese mensaje con el testimonio de los filósofos y, sobre todo, de Aristóteles, hasta hacer de ambos una misma realidad: "¿Qué tiene que ver Cristo con Aristóteles o los misterios de eterna sabiduría con la sutil sofistería?"'. Esto no significa que no aprecie en las obras de los filósofos aportaciones valiosas,

\footnotetext{
4 W. F. Bense, Paris Theologians on War and Peace, 1521-1529, "Church History", 41(1972) págs.168-85.

5 Erasmo, "La guerra atrae a quienes no la han vivido" (Dulce bellum inexpertis), en Adagios del poder y de la guerra y Teoría del adagio, ed. de R. Puig de la Bellacasa, Madrid, Alianza Ed., 2008, pág. 201: "si alguien considera el aspecto y la forma del cuerpo humano, ¿no percibirá enseguida que la naturaleza - o más bien Dios- creó a este animal no para la guerra sino para la amistad, no para la perdición sino para la salvación, no para la agresión sino para la clemencia?".

${ }^{6}$ Ibídem, pág. 202: "sólo el hombre nace en un estado que por mucho tiempo le obliga a depender totalmente de la ayuda ajena...; se trata del único animal nacido exclusivamente para la amistad, que principalmente madura y se refuerza con la ayuda mutua".

${ }^{7}$ Erasmo, Elogio de la locura, int., trad. y notas de P. Rodríguez Santidrián, Madrid, Alianza Edit., 2008, pág. 129: "la guerra es... tan impía que nada tiene que ver con Cristo".

8 Ibídem, pág. 170; La Paráclesis, en Erasmo, El Enquiridion o Manual del caballero cristiano, ed. de D. Alonso, prólogo de M. Bataillon, y La Paráclesis o Exhortación al estudio de las letras divinas, ed. y prólogo de D. Alonso (Traducciones españolas del siglo XVI); Madrid, 1971 (Revista de Filología Española, Anejo XVI), pág. 459: "yo os prometo que si estas cosas que llaman baxas cumpliessen por obra como deven los príncipes, y los predicadores las dixessen muchas vezes en los sermones, y si los preceptores las enseñasen a los muchachos en los estudios, y no aquellas cosas curiosas que de las fuentes de Aristóteles y de Averroys se toman, que no andaría por todas partes la religión christiana como anda rebuelta"; "La guerra atrae a quienes no la han vivido", pág. 226; etc.
} 
pero, aunque no excluya la utilidad de sus ideas para la religión, deben dejar incontaminada la teología; así, Erasmo valora los textos platónicos por su apertura, que proporciona, como la Biblia, todo tipo de imágenes, a la vez que aportan ideas útiles para el cristianismo ${ }^{9}$, pero no acepta su mezcla o confusión.

El humanista de Rotterdam es uno de los hombres de su tiempo más dotado de conocimientos clásicos y erudición, pero lo que reivindica para la vida es el mensaje de Cristo. Éste le sirve de base cuando escribe sus apelaciones a los gobernantes civiles y papas, para que no participen en lucha alguna, ni pongan en ellas su empeño ${ }^{10}$. Espera de ellos una respuesta positiva no sólo porque son los únicos a los que atribuye capacidad decisoria en los asuntos de gobierno, sino porque tiene una mala opinión tanto del pueblo, cuya ignorancia desprecia, como de los nobles, cuyas reivindicaciones le parecen egoístas ${ }^{11}$.

Esa misma inspiración cristiana y ese desprecio por el vulgo se unen a la confianza en el valor de la educación ${ }^{12}$ para llevar adelante las reformas con las que soñaba Erasmo. Todo ello alimenta su crítica de los soldados como personajes pendencieros y de escasa moralidad, dispuestos a poner en peligro su vida y la de los demás con cualquier excusa. El reproche por entregarse a duelos y desafíos sin necesidad, se mezcla con la denuncia de la propia actividad militar, más dada a los excesos que a la contención, más a ensalzar los actos violentos, peligrosos y desmesurados que los tranquilos, pacíficos y templados. Esta última actitud, que lleva al perdón de las injurias, es la que debe caracterizar a los ojos de Erasmo al verdadero caballero cristiano:

"Mas dime, ¿qué cosa ay más lexos de la magnanimidad y grandeza de coraçón que moverte por una palabrilla y salir desatinadamente fuera de razón, y ser de

\footnotetext{
${ }^{9}$ Erasmo, El Enquiridion o Manual del caballero cristiano, pág. 161: Platón como inspirador del control del alma sobre las pasiones; pág. 175 (habla de dos almas como San Pablo de dos hombres), p. 238 (sentido literal y profundo de su escritura, como las Sagradas), y véase págs. 167, 291-3, 298, 384, etc.; Elogio de la locura, pág. 146; etc.

10 "La guerra atrae a quienes no la han vivido", págs.. 250-3; "Los silenos de Alcibíades", en Adagios del poder y de la guerra y Teoría del adagio, ed. cit., pág. 119; "El 'Antipolemos', refutación de los motivos oficiales de la guerra", en ibídem, págs.. 246-50.

${ }^{11}$ El Enquiridion o Manual del caballero cristiano, págs. 159-60: "Porque ninguna cosa ay más desconcertada ni torpe que la gente baxa y común del pueblo, y por esso ha siempre de obedecer a los que goviernan, y no ser parte para governar. Los que fueren principales y de mayor edad y autoridad han de ser admitidos y oydos sus votos en las consultas de lo que se debe hazer, pero de tal manera que la determinación y el cargo de mandar y disponer en todo, siempre se reserva a solo el rey, el qual cumple que algunas vezes sea aconsejado y amonestado, pero no conviene que jamás sea forçado, ni que piense ninguno passarle delante. Este rey a ninguno ha de ser sujeto sino a la ley; y la ley ha de ser conforme a toda honestidad. Mas si anda lo de arriba abaxo, con tal desorden que el vulgo desconcertado y aquella hez reboltosa de la ciudad se suelta a querer mandar, no haziendo caso de aquellos a quien debe acatar; o si los grandes y principales no reconocen obediencia a su rey, luego nace en esta tal república un tan peligroso alboroto y discordia, que si Dios con su dictadura y divino poder no socorre, está a punto de perderse y assolarse toda". Véase "Los silenos de Alcibíades", pág. 119.

${ }_{12}$ D. R. Kelley, Renaissance Humanism, Boston, Twayne Publishers, 1991, pág. 53: para Erasmo "la reforma social y religiosa estaba basada sobre individuos adecuadamente educados y motivados".
} 
tan poco poder para despreciar la locura agena, que no lo puedas acabar contigo ni te tengas por ombre, si no sobrepujas el maleficio de los otros con tus malas obras? ¡O quánto más esforzada cosa sería poder olvidar y tener en poco todas las injurias con un gran coraçón y ecelente, y mucho más hazer bien y mercedes a quien te oviesse hecho malas obras! No tengo yo por fuerte al que acomete a su enemigo, ni al que escala las fortalezas, ni al que, teniendo en poco la vida, pone a mil peligros su cabeça, pues estas cosas las hazen cada día algunos soldados, no tanto por virtud quanto desatinados. Mas a aquel se deve renombre de fuerte y se le dará gualardón de magnánimo que pudo vencer su propio coraçón, que puede querer bien a quien mal le quiere, y hazer bien a quien mal le haze, y dessear bien a quien mal le dessea" ${ }^{13}$.

Niega también Erasmo que el verdadero cristiano se pueda desentender del mensaje evangélico cuando se sumerge en la vida civil. Los que suponen que unas son las obligaciones para los que aspiran a la santidad y otras para los que se dedican a la vida activa se equivocan ${ }^{14}$. El modo de vida que se desprende de los evangelios es el mismo para todos los cristianos ${ }^{15}$.

La defensa que el holandés hace de que "después de que Cristo ordenase envainar la espada no es digno de cristianos hacer la guerra"; su insistencia en que "su vida y su doctrina no predican otra cosa que la tolerancia"; que el Evangelio no indica sino "el fin hacia el que había que orientarse con todas las fuerzas" y ese fin no es otro que la doctrina del amor y el rechazo de la violencia ${ }^{16}$, no deja lugar a dudas. En sus argumentaciones, pasajes como el que ordena dar el manto al que se apodera de la túnica y ofrecer la otra mejilla al que es víctima de una agresión ${ }^{17}$, son oportunamente utilizados ${ }^{18}$, para dejar claro que la guerra es incompatible con el cristianismo. Fuese quien fuese el enemigo, el ejercicio de la guerra tiene poco de cristiano: "Yo considero que ni siquiera contra los turcos debe declararse una guerra a la ligera, ante todo porque pienso que el reino de Cristo se originó, se propagó y se consolidó por un camino totalmente distinto"19.

${ }^{13}$ El Enquiridion o Manual del caballero cristiano, pág. 315.

14 J. Ginés de Sepúlveda, Obras completas VI. Gonzalo, diálogo sobre la apetencia de gloria, introducción, edición crítica y traducción de J. J. Valverde Abril, Excmo. Ayuntamiento de Pozoblanco, 2001, p. 243: "Verdaderamente una cosa conviene al soldado y otra bien distinta al monje; éste soportará con absoluta paciencia las afrentas, no tomará venganza ni siquiera de palabra de aquéllos que cometan injusticia contra él; si alguien lo amenaza con herirlo, sencillamente debe huir, no intentará responderle con armas. Esto es lo honesto para el monje, esto es lo glorioso, esto es lo digno de alabanza. ¿Pero qué honorable general elogiará ese comportamiento en un soldado valeroso? Es más, ¿quién no lo criticará y dirá a voces que atenta contra el deber y el honor de un soldado?”.

15 "La guerra atrae a quienes no la han vivido", pág. 235: "la gracia evangélica... ordena que no maldigamos a los que nos maldicen, que hagamos el bien a los que nos hacen mal, que demos todas nuestras posesiones a quien nos quita una parte, que roguemos por aquellos que intentan matarnos. 'Estas cosas' -afirman ellos [los que aprueban la guerra]- 'valen para los apóstoles'. ¡No! Más bien, como hemos dicho, valen para el conjunto del pueblo y del cuerpo de Cristo, que conviene que sea un todo absoluto".

${ }_{16}$ Ibídem, págs. 232, 233 y 234.

17 Mateo 5, 38-42.

18 "La guerra atrae a quienes no la han vivido", pág. 235.

19 Erasmo, Educación del príncipe cristiano, estudio preliminar de P. Jiménez Guijarro; traducción 
Es esta incompatibilidad la que le lleva a contestar con radicalidad que pueda darse una guerra santa $^{20}$, con el mismo énfasis con el que rechaza que existan guerras justas $^{21}$. Erasmo también ve absurda cualquier exigencia a los herejes cuando hay tanto que reformar en las costumbres de los católicos: "Saquemos primero la viga de nuestro ojo y después la paja del ojo del hermano"22. Incluso polemiza con las interpretaciones a las que son dados muchos de sus críticos, cuando recurren a la literatura veterotestamentaria para dar validez a las guerras de los judíos como antecedente de las de los cristianos ${ }^{23}$.

La ley antigua perdió su validez una vez que Cristo trajo la nueva. Sus ejemplos no son válidos para los cristianos, que tienen en los evangelios modelos mucho más perfectos en los que posar su vista ${ }^{24}$. Erasmo, llevado precisamente por su oposición a las guerras que allí se narran, prefiere optar por una interpretación no literal del Antiguo Testamento, que relegaría a meras alegorías y prefiguraciones del Nuevo:

"Debe advertirse al príncipe que no considere imitable al pie de la letra todo lo que leyere en los libros sagrados. Aprenda que las luchas y matanzas de los hebreos y su crueldad contra los enemigos deben ser interpretadas alegóricamente ya que, de no ser así, resulta perniciosa su lectura. Pues una cosa es lo que se permitió a aquel pueblo en función de su época y otra muy diferente lo que se le ha transmitido al pueblo de los cristianos como ciudadanos del cielo"25.

Ni guerra santa, ni justa, ni enfrentamiento con los herejes por la verdadera religión, ni aceptación del modelo del Antiguo Testamento. Erasmo considera que la guerra, si tuvo sentido en algún momento, es una práctica que el mensaje de amor del Nuevo Testamento vino a extinguir. De ahí su resistencia a aceptarla, incluso en aquellos casos, como contra los turcos, en los que no parecía existir otra solución. Muy al contrario, sólo excepcionalmente debería concebirse esa

de P. Jiménez Guijarro y A. Martín, Madrid, Tecnos, 1996, pág. 176.

20 "La guerra atrae a quienes no la han vivido", pág. 214: "Hay quienes aplauden, quienes la glorifican, quienes califican de santa una cosa más que infernal".

${ }^{21}$ Ibídem, pág. 233; Educación del príncipe cristiano, pág. 168; etc.

22 "La guerra atrae a quienes no la han vivido", pág. 244.

${ }^{23}$ Ibídem, pág. 232: "si tanto nos agrada el ejemplo de los judíos ¿por qué, de la misma manera, no nos cortamos el prepucio? ¿Por qué no nos abstenemos de la carne porcina? ¿Por qué cada uno de nosotros no contrae matrimonio con varias esposas? ¿Por qué, mientras condenamos esas prácticas, sólo nos parece bien el ejemplo de la guerra?". Sin embargo, en la "Utilísima consulta acerca de la declaración de guerra al turco" (1530), en Erasmo, Obras escogidas, ed. de L. Riber, Madrid, Aguilar, 1964, pág. 1008, parece admitir las guerras de los hebreos, del mismo Moisés e incluso la aceptación de la espada por san Pablo.

${ }^{24}$ La Paráclesis, pág. 463: "Si hallamos que ay otras doctrinas que más enteramente nos muestren a ser christianos, dexada la de Christo, sigamos aquélla; pero, si sóla ésta es la que nos puede hazer verdaderamente christianos, ¿por qué casi queremos tener las letras evangélicas por más sin provecho y desechadas que los libros de Moysen?".

25 Educación del príncipe cristiano, pág. 99; El Enquiridion o Manual del caballero cristiano, págs. 243-4.

Araucaria. Revista Iberoamericana de Filosofia, Política y Humanidades, año 16, n 32. Segundo semestre de 2014. Pp. 25-52. ISSN 1575-6823 e-ISSN 2340-2199 doi: 10.12795/araucaria.2014.i32.02 
posibilidad, incluso frente a quien concita tanta beligerancia como los turcos ${ }^{26}$. La razón de ello es que no los ve únicamente como enemigos con los que sólo cabe el enfrentamiento. Intenta una aproximación que va más allá de la fuerza. Los utiliza para llamar la atención de los cristianos por sus relajadas costumbres, para introducir dudas sobre la corrección de sus comportamientos, para ejercer la crítica de la práctica religiosa de muchos de ellos; en suma, en contra de la tendencia predominante en su tiempo, que los presentaba como auténticos "azotes de Dios"27, Erasmo se sirve de la comparación entre cristianos y turcos para relativizar su supuesta maldad: "si prescindes del nombre y de la insignia de la cruz somos turcos que luchan contra turcos" 28 .

Las convicciones pacifistas de Erasmo están tan asentadas que incluso cuando parece ceder y aceptar la posibilidad de la guerra, sus textos insisten más en extremar los condicionantes de la misma, que en dar rienda suelta a su realización. Por eso, criticó lo que había en esa lucha de ambición territorial, denunciando que la propuesta de hacer de la guerra contra el turco la base de un imperio era ajena al cristianismo: "Si nuestro empeño es propagar el imperio, si ambicionamos las riquezas de aquéllos ¿por qué disfrazamos una empresa tan profana con el nombre de Cristo?" 29 .

Si la intervención en la guerra con el turco se hacía al servicio de las finalidades del poder político, nada tenían que ver con ella los cristianos, y si se justificaba como una guerra para hacer frente a su agresión, no deberían dejarse de lado los principios cristianos: "Esto no quiere decir que yo condene toda expedición contra los turcos en caso de que tomen la iniciativa de atacarnos, sino que una guerra que atribuimos a Cristo la conduzcamos con espíritu cristiano y con las armas de Cristo"30. Ésta fue la actitud de Erasmo durante toda su vida; si su rechazo a la guerra es radical en la Dulce bellum inexpertis y en la Querella pacis, la posterior Utilissima consultatio de bello turcis inferendo, en realidad una larga carta del 17 de marzo de 1530, dirigida al profesor de derecho civil y canónico Johan Rinck de Colonia, viene a desarrollar esta postura ${ }^{31}$. El resultado de tales prevenciones en un ambiente

\footnotetext{
26 "La guerra atrae a quienes no la han vivido", págs. 245-6.

27 C. A. Patrides, 'The Bloody and Cruell Turke': The Background of a Renaissance Commonplace, "Studies in the Renaissance", 10 (1963), pág. 130.

28 "La guerra atrae a quienes no la han vivido", págs. 242, 243-4: "escupimos a los turcos y de este modo nos consideramos nobles cristianos, cuando somos para Dios más abominables quizás que esos mismos turcos"; "esos que llamamos turcos son en su mayoría semicristianos y quizás estén más cerca del verdadero cristianismo que la mayoría de nosotros", etc.; véase "Utilísima consulta acerca de la declaración de guerra al turco", pág. 1013.

29 "La guerra atrae a quienes no la han vivido", pág. 244; véase R. G. Musto, "Just Wars and Evil Empires: Erasmus and the Turks", en J. Monfasani y R. G. Musto (eds.), Renaissance society and culture: essays in honor of E. F. Rice, Jr., New York, Italica Press, 1991, págs. 197-216.

30 "La guerra atrae a quienes no la han vivido", págs. 245-6.

31 "Utilísima consulta acerca de la declaración de guerra al turco", pág. 1015: "Aquí por ventura a alguien se le antojará que yo tomé la empresa de desaconsejar la guerra turca. De ningún modo; hágolo más bien porque luchemos con ellos felizmente, y reportemos para Cristo legítimos y hermosos triunfos".
} 
mayoritariamente favorable a una guerra sin limitaciones, condicionó tanto la recepción de su mensaje como la consideración hacia su persona. Su actitud de abrirse a la posibilidad de guerra contra el turco siempre pareció forzada y tibia a los partidarios abiertos de la misma e incluso, tras las circunstancias del cerco otomano de Viena en 1529, sus prevenciones les resultaron intolerables. Su figura fue atacada e incluso acusada de connivencia y traición ${ }^{32}$. A pesar de ello, hay que insistir en que Erasmo, aunque durante toda su vida mantuvo la incompatibilidad entre el cristianismo y la acción militar ${ }^{33}$, no había rechazado enteramente la guerra con el turco, sino su desarrollo más allá de lo necesario. Esta posición era, no obstante, difícil de mantener. Ni siquiera en el círculo imperial, donde predominaban las simpatías hacia el holandés, se veía factible evitar el desafío. El irenismo erasmiano no se consideraba una alternativa coherente ante la agresión militar ${ }^{34}$. Incluso un autor como Juan Luis Vives, que siempre se ha identificado con ese pacifismo ${ }^{35}$, mantuvo una postura mucho más comprometida a favor de la guerra contra $\operatorname{los} \operatorname{tur} \cos ^{36}$, advirtiendo del peligro de nuevas derrotas para la forma de vida cristiana y europea ${ }^{37}$.

\section{La teoría escolástica de la guerra}

La escolástica española venía desarrollando una teoría de la guerra justa que hunde sus raíces en las enseñanzas de Sto. Tomás. Sin embargo, hay que esperar a las relecciones ${ }^{38}$ de Francisco de Vitoria en la Universidad de

\footnotetext{
32 J. Ginés de Sepúlveda, Obras completas VII. Exhortación a Carlos V. Edición crítica, traducción e introducción filológica de J. M. Rodríguez Peregrina. Introducción histórica de B. Cuart Moner. Excmo. Ayuntamiento de Pozoblanco, 2003, pág. 334.

33 J.-C. Margolin, Guerre et paix dans la pensée d'Érasme, introduction, choix de textes, commentaires et notes par...; Paris, Aubier Montaigne, 1973, y M. Bataillon, "Un extremo del irenismo erasmiano en el adagio «Bellum»" (1969), en M. Bataillon, Erasmo y el erasmismo, trad. de C. Pujol, Barcelona, Crítica, 1983, págs. 64-79.

34 J. A. Fernández Santamaría, Erasmus on the just war, "Journal of the History of the Ideas", XXXIV (1973), págs. 209-26 (215), y Juan Ginés de Sepúlveda: la guerra en el pensamiento político del Renacimiento. Madrid, C.E.P. y C., 2007, págs. 52 y ss.

35 J. A. Fernández Santamaría, El estado, la guerra y la paz. El pensamiento político español en el Renacimiento, 1516-1559. Madrid, Akal, 1988, págs. 59-67.

36 J. L. Vives, "De la insolidaridad de Europa y de la guerra contra el turco" (1526), pp. 39-61, y "De la condición de los cristianos bajo el turco" (1526), pp. 63-74, en J. L. Vives, Obras Completas, II; trad., comentarios y notas de L. Riber; Madrid, M. Aguilar - Generalitat Valenciana, 1948 (1992).

37 E. V. George, "Juan Luis Vives De Europea dissidiis et bello Turcico: Its Place in the 1526 Ensemble", J. F. Alcina et al. (eds.), Acta Conventus Neo-Latini Bariensis, Tempe, 1998, pp. 259266; J.-C. Margolin, "Conscience européenne et réaction á la menace turque d'après le «De dissidiis Europae et bello turcico» de Vives (1526)", A. Buck (ed.), Juan Luis Vives; Hamburg, Ernst Hanswedell et co., 1982, pp. 107-40.

38 Una relectio o repetición era una conferencia de dos horas de duración que los profesores de algunas universidades estaban obligados a dar cada año en días no lectivos sobre la materia que habían desarrollado en las lectiones ordinarias del curso. Véase F. Castilla Urbano, El pensamiento de Francisco de Vitoria. Filosofía politica e indio americano, Barcelona, Anthropos, 1992.
} 
Salamanca, para que esta teoría alcance su mayor originalidad e interés en relación con los asuntos contemporáneos. Las propuestas de este catedrático de Teología estaban destinadas, a su vez, a tener continuidad entre sus discípulos y los discípulos de éstos durante casi un siglo, tanto en Europa como en el continente americano, hasta el jesuita Francisco Suárez, que representa la culminación de la teoría.

A inicios del siglo XVI tanto la autoridad del papa como la del emperador hacía tiempo que habían quedado invalidadas para establecer el gobierno del mundo; sólo el recurso a los estados nacionales se prestaba a dar fundamento a un nuevo orden. La teoría de la guerra justa de Vitoria adquiere su sentido más profundo en el marco que establecen las relaciones entre esos estados. Éstas se rigen por el derecho de gentes. El dominico va a interpretar la tradición tomista sobre este derecho haciendo del mismo un derecho positivo cuyas normas, no obstante, no pueden ser abolidas de la misma forma que las del derecho positivo. El pacto de todo el orbe para crear el derecho de gentes otorga a éste un poder que rebasa el de su mismo origen, para convertirse en una "fuerza de ley" ${ }^{39}$ que "es derecho natural o se deriva del derecho natural" 40 . Además, Vitoria convierte el derecho de gentes que hacía de los seres humanos el sujeto de sus disposiciones en un ius inter gentes, que otorga ese protagonismo a las naciones ${ }^{41}$.

El bien común del orbe es la finalidad que debe guiar las prácticas interestatales. Las normas del derecho de gentes buscan ese bien que haría imposible la convivencia entre los países y la humanidad misma si no se cumpliera. Para impedir que eso ocurra, es necesario establecer una autoridad que garantice el respeto a las normas establecidas. Sin embargo, el derecho de gentes, aunque "tiene verdadera fuerza de ley", es fruto del pacto entre las naciones y, más allá del compromiso de cada nación con ese pacto, no impone ninguna autoridad internacional capaz de cumplir y hacer cumplir lo acordado. No hay fuera del estado una autoridad que garantice el cumplimiento de las leyes y el mantenimiento del orden; por eso insiste Vitoria en que el orbe sólo "en cierta manera forma una república". La función de la autoridad internacional deberá ser ejercida por quienes la poseen en el ámbito de sus

${ }^{39}$ De potestate civili, en F. de Vitoria, Obras. Relecciones teológicas, edón. T. Urdánoz, Madrid, BAC, 1960, págs. 191-2: “el derecho de gentes no sólo tiene fuerza por el pacto y convenio de los hombres, sino que tiene verdadera fuerza de ley. Y es que el orbe todo, que en cierta manera forma una república, tiene poder de dar leyes justas y a todos convenientes, como son las del derecho de gentes. De donde se desprende que pecan mortalmente los que violan los derechos de gentes, sea de paz, sea tocantes a la guerra, en los asuntos graves como en la inviolabilidad de los legados. Y ninguna nación puede darse por no obligada ante el derecho de gentes, porque está dado por la autoridad de todo el orbe".

${ }^{40}$ F. de Vitoria, Relectio de indis, edón. L. Pereña, Madrid, CHP-CSIC, 1967, pág. 78.

${ }^{41}$ Vitoria, en un cambio que sólo puede tener como objetivo subrayar el nuevo sentido que se pretende introducir, habría modificado en la De indis (pág. 78), la definición clásica de Gayo, sustituyendo homines por gentes: "Quod naturalis ratio inter omnes gentes constituit, vocatur ius gentium". 
comunidades respectivas, no tanto como representantes de éstas, sino como delegados del orbe ${ }^{42}$.

La reparación de la injusticia entre naciones alcanza su expresión última en la doctrina de la guerra justa. En ésta debemos distinguir entre el derecho a la guerra (ius ad bellum), el derecho sobre cómo conducir la guerra (ius in bello), y el derecho tras la guerra (ius post bellum). Sobre el primero hay que señalar que en el origen de la guerra justa debe estar una autoridad que posee capacidad para declararla. Mientras defiende una causa justa esta autoridad legítima no lucha por sí, sino en representación del orbe ${ }^{43}$. Si el príncipe de una república perfecta, esto es, "que tiene leyes propias, parlamento propio y magistrados propios, como lo son el reino de Castilla y de Aragón y otros por el estilo" 44 , no puede tolerar que el territorio que gobierna sea presa del abuso sin tomar medidas que lo corrijan, tampoco podrá aceptar que el orbe se instale en el desorden ${ }^{45}$. Por supuesto, Vitoria es consciente de que esta delegación puede ser utilizada, como con frecuencia se hace con la religión, la expansión territorial, la gloria o cualquier otra excusa ${ }^{46}$, para justificar la guerra, por eso insiste en que la guerra requiere la seguridad plena por parte del gobernante acerca de su justicia. En caso de que existan dudas sobre su licitud, el príncipe debe pedir consejo a personas independientes y con criterio, para que expresen su opinión sin pasión; todo antes que tomar una decisión tan delicada como la participación en la guerra, sin la máxima certeza de su justicia e inevitabilidad ${ }^{47}$. Además, debe haber razones de proporcionalidad: la única razón de la guerra justa es la reparación de la injusticia, y esa injusticia debe ser extremadamente grave para que requiera hacer uso de la misma ${ }^{48}$. Incluso introduce Vitoria

${ }^{42}$ A. Truyol Serra, Prémisses philosophiques et historiques du Totius orbis de Vitoria, "Anuario de la Asoc. F. de Vitoria”, VII (1946-7), págs.. 179-201.

${ }^{43}$ F. de Vitoria, Relectio de iure belli, edón. L. Pereña, Madrid, CHP-CSIC, 1981, pág. 137: "Nótese en orden a la prueba que los príncipes no sólo tienen autoridad sobre sus súbditos sino también sobre los extranjeros para disuadirles de que no vuelvan a cometer injusticias y esto por derecho de gentes y por autoridad de todo el orbe. Es más, parece que incluso por derecho natural, pues parece que de otro modo no podría subsistir el orbe si no residiese en algunos fuerza y autoridad para disuadir a los malvados y evitar que dañen a los inocentes".

44 Ibidem, pág. 119.

45 Ibídem, pág. 109: "Se haría del todo imposible el mantenimiento de la tranquilidad en la tierra e incluso la situación general del orbe sería caótica si los tiranos, los ladrones y los secuestradores pudiesen impunemente cometer sus crímenes y oprimir a buenos e inocentes, y no fuese, a su vez, lícito a los inocentes tomar escarmiento de los culpables".

${ }^{46}$ Ibidem, págs. 124-5.

${ }^{47}$ Ibídem, pág. 141: "dada la gran dificultad que existe en asuntos morales de dar con la verdad y la justicia, será fácil errar si se tratan estos asuntos con negligencia, y este error no excusará a sus autores, mayormente en asunto de tanta importancia en que se trata del peligro y de la ruina de muchos, que, en definitiva, son prójimos nuestros a los que estamos obligados a amar como a nosotros mismos".

48 Ibídem, pág. 129: "Siendo, por tanto, tan graves y atroces todos los males que resultan de la guerra como son asesinatos, incendios y devastaciones, no es lícito por delitos leves acudir a la guerra para castigar a sus autores -ya que proporcionado a su delito será el número de azotes (Deuteronomio, $25,2)$-, sino castigar como corresponde a la gravedad de los delitos. Luego no es lícito hacer la guerra por cualquier culpa o injuria".

Araucaria. Revista Iberoamericana de Filosofía, Política y Humanidades, año 16, n 32 . Segundo semestre de 2014. Pp. 25-52. ISSN 1575-6823 e-ISSN 2340-2199 doi: 10.12795/araucaria.2014.i32.02 
una cláusula que pretende ser una garantía para aquellos casos en los que los males que se seguirían de la guerra justa serían mayores que las ventajas, lo que convierte en improcedente su realización ${ }^{49}$.

La guerra, aunque sea justa, es un mal y conviene evitarla por todos los medios. De hecho, la propia amenaza de la guerra puede desempeñar una función preventiva que no hay que desdeñar ${ }^{50}$. Sin embargo, una vez que se comete la injusticia y no hay otro medio de repararla, la guerra justa se muestra en su función genuina encaminándose a restaurar la situación anterior a la conculcación del derecho.

Cuando existe una autoridad legítima que declara la guerra, una causa justa, no cabe otro recurso al que recurrir, existe proporcionalidad en las acciones a emprender y se da una probabilidad de éxito, queda resuelta la cuestión del ius ad bellum y llega el turno del ius in bello. Para Vitoria, "en guerra justa es lícito hacer todo lo que sea necesario al bien público y para defensa del bien público" 51 . No hay que olvidar que "toda la república puede ser lícitamente castigada por el pecado del rey", lo que avala el derecho del injuriado a recuperar los bienes que se hayan podido perder, resarcirse de los gastos en que se ha incurrido, e incluso la toma de rehenes y la confiscación de naves, armas y, en general, todo cuanto se considere necesario para evitar nuevas amenazas, incluyendo "saquear y proseguir todos los otros derechos de guerra hasta dar muerte a los súbditos del rey, aunque ellos sean inocentes" ${ }^{\prime}$.

Aunque este planteamiento parece excluir cualquier limitación a lo permitido en una guerra justa, no es fácil atribuir a Vitoria una conclusión tajante. Por una parte, el dominico siempre advierte contra los excesos innecesarios ${ }^{53}$. Por otra parte, la guerra que busca establecer la justicia no deja de ser una guerra y, como tal, no es ajena a la reparación a toda costa de los males recibidos ${ }^{54}$, incluso con episodios de crueldad $^{55}$. Vitoria no se refiere sólo

${ }^{49}$ Ibídem, pág. 161: “es obligado observar que es compatible una guerra justa de suyo e ilícita e injusta por alguna circunstancia. Es compatible, sin duda, que alguien tenga derecho a recobrar una ciudad o una provincia y, sin embargo, resulte totalmente ilícito por razón del escándalo. Porque como antes hemos dicho- las guerras deben hacerse para el bien común, y si para recobrar una ciudad necesariamente han de seguirse mayores males a la república, tales como destrucción de muchas ciudades, etc., provocación de los príncipes, ocasiones para nuevas guerras, es indudable que tal príncipe está obligado a ceder en su derecho y abstenerse de la guerra". Véase De potestate civili, pp. 167-8.

${ }^{50}$ Ibídem, pág. 107: "El fin de la guerra es la paz y la seguridad de la república, como dice Agustín. Y no podrá haber seguridad en la república si no se disuadiese al enemigo de cometer injusticia con el temor de la guerra".

51 Ibídem, pág. 132.

${ }^{52}$ De potestate civili, pág. 167; véase De iure belli, pág. 135.

53 De iure belli, pág. 173: "Si la guerra puede llevarse bien sin necesidad de despojar a los labradores y a otros inocentes, no parece que sea lícito despojarlos".

54 Ibídem, pág. 175: "Si los enemigos se niegan a restituir los bienes arrebatados injustamente y el perjudicado no pudiera resarcirse buenamente de otro modo, puede tomar satisfacción de donde sea, tanto a costa de los culpables como de los inocentes".

55 Ibídem, pág. 177: "se puede, si es preciso para el fin de la guerra hacer prisioneros incluso a los 
a accidentes en los que los civiles sufren las consecuencias de acciones que iban dirigidas contra los que luchan ${ }^{56}$; se trata de situaciones en las que los inocentes padecen las consecuencias de la guerra como si participaran en ella, porque de no hacerlo sería imposible alcanzar los objetivos que requiere la victoria y, con ello, la justicia:

\begin{abstract}
"en algún caso es lícito matar inocentes aun a sabiendas; por ejemplo, cuando se ataca justamente una plaza fuerte o una ciudad dentro de la cual se sabe que hay otros inocentes, y no se puede disparar los cañones u otros proyectiles o incendiar edificios sin que resulte daño tanto para los inocentes como para los culpables. De otro modo no podría hacerse la guerra contra los culpables mismos y quedaría frustrada la justicia de los que hacen la guerra. Y al contrario, es lícito disparar cañones y otros proyectiles contra los sitiadores y el campamento enemigo -si la ciudad es objeto de un ataque injusto y ella se defiende justamente- aunque entre ellos haya algunos niños o inocentes" 57.
\end{abstract}

Salvo que haya otra alternativa menos cruel a la que recurrir, el ius in bello vitoriano se aferra a la legitimidad que le da estar al servicio de la justicia y de la paz, es decir, de formar parte de una guerra justa, para autorizar casi cualquier práctica violenta. Pero la consecución del bien del orbe no puede consistir en la mera derrota del agresor. Si la acción punitiva se realiza por delegación del orbe, la administración de la victoria no puede ser ejercida sin su control. Esto supone que en el ius post bellum la imposición de medidas debe moverse en un equilibrio que, por una parte, restaure justamente los daños ocasionados y, por otra, no genere una cadena de agravios que conduzca inevitablemente a un nuevo enfrentamiento. Para ello es necesario que el príncipe tenga en cuenta en todo momento que actúa por delegación del orbe, y se comporte con los derrotados más como juez que como parte, sobre todo, sabiendo que muchos de los que participan en las guerras se limitan a depositar su confianza en sus líderes, dando por supuesto que, puesto que éstos aprueban la guerra, ésta está justificada:

"Conseguida la victoria y terminada la guerra, se debe usar de la victoria con
moderación y modestia cristianas, y conviene que el vencedor se considere a sí
mismo como juez que se sienta para juzgar a dos repúblicas, una la ofendida,
otra la que perpetró la injuria. De manera que no dicte sentencia como acusa-
dor sino como juez dé satisfacción a la república ofendida. Pero en cuanto sea
posible sin ruina de la república agresora. Tanto más cuanto que las más de las

inocentes, como son los niños y las mujeres, no para reducirlos a esclavitud sino para exigir rescate por ellos".

${ }_{56}$ Ibídem, pág. 169: "nunca parece lícito aplastar a inocentes, ni siquiera eventualmente y sin intención, a no ser cuando las conveniencias de una guerra justa así lo piden y no es posible proceder de otro modo".

${ }^{57}$ Ibídem, pág. 167; ibídem, pág. 179: "En el fragor mismo del combate, sea en el ataque o en la defensa de una ciudad, es lícito matar indiferentemente a todos los que pelean en contra, y desde luego mientras dura la situación de peligro". 
veces, sobre todo entre los cristianos, toda la culpa es de los príncipes, pues los súbditos pelean de buena fe por sus príncipes. Y es una iniquidad que, como el poeta dice (Horacio, Epístolas, I, 2, 14), paguen los aqueos los delirios de sus reyes $"$.

A pesar de esta salvaguarda, la doctrina del príncipe como juez no va más allá de ser la expresión de un bienintencionado deseo de Vitoria. Nada garantiza que el vencedor de la guerra justa se comporte como juez y, desde luego, nada, ni la autoridad del orbe, le obliga a ello. Puede ocurrir, además, que no se produzca su victoria, sino que ésta corresponda al agresor injusto, lo que no sólo excluiría la idea del vencedor como un juez imparcial, sino que haría imposible la justicia. Sin embargo, cuando efectivamente se produzca la victoria del agredido injustamente, su deber moral es actuar con equidad, teniendo en cuenta el alcance de la injuria, los prejuicios causados y cuantos delitos se hayan cometido, pero sin caer en la crueldad ni en la venganza ${ }^{59}$. Cabe, por supuesto, imponer tributos a los vencidos para indemnización de los daños e incluso para castigar la acción injusta ${ }^{60}$. Asimismo, no es ilícito tomar las precauciones suficientes para evitar que en el futuro se reproduzca una situación similar: "Para conseguir la seguridad y alejar peligros de enemigos, es lícito también ocupar o retener alguna plaza fuerte o ciudad enemiga que sea necesaria para nuestra defensa o para quitar a los enemigos ocasión de inferir posibles daños" $"$.

Pero estaría fuera de toda proporción que el vencedor de la guerra justa se cobrara una compensación que excediera ampliamente los daños y agravios provocados $^{62}$, o que la medida impuesta, como "deponer a los príncipes enemigos y poner en su lugar a otros o quedarse con el poder"63, fuera de una inhumanidad exagerada.

En realidad, cuando Vitoria piensa en el príncipe que vence en la guerra justa como un juez, no establece que tenga que ser cristiano, pero parece claro que lo concibe adornado con las virtudes del caballero cristiano. De aquí deriva su creencia en la justicia de su actuación y en la caridad que había de exhibir ante el vencido.

${ }^{58}$ Ibídem, pág. 205. Vitoria mantiene que los ciudadanos pueden participar en la guerra confiando en sus gobernantes, salvo que los indicios de injusticia fueran tan claros que no hubiera excusa para no plantearse su licitud. En caso de suponer la injusticia de la guerra, considera que no deben obedecer, estén o no equivocados.

59 Ibidem, pág. 183.

${ }^{60}$ Ibídem, pág. 199.

${ }^{61}$ Ibidem, pág. 195.

${ }_{62}$ Ibídem, pág. 191: "No ha de entenderse, pues, que si los franceses destruyeran una aldea o una villa insignificante de España, es lícito a los españoles saquear -aun pudiendo- toda Francia. La réplica ha de ser moderada y proporcionada al agravio".

${ }^{63}$ Ibidem, pág. 199. 


\title{
4. El protestantismo ante la guerra
}

No hay en Lutero una teoría de la guerra en sentido estricto, aunque, a pesar de la confusión que rodea todo el asunto en el pensamiento del alemán, resulta clara la aproximación de sus ideas a la doctrina de la guerra justa. La aceptación de la guerra por parte de Lutero se justifica recurriendo a su doctrina de los dos reinos: "Los que pertenecen al reino de Dios son los que creen rectamente en Cristo y están bajo él" ${ }^{64}$; el gobierno de éstos es "espiritual, por la palabra y sin la espada, por el que los hombres se hacen justos y piadosos a fin de obtener con esa justicia la vida eterna; esta justicia la administra él mediante la palabra que ha encomendado a los predicadores" ${ }^{" 5}$. Frente al reino de Dios está el reino del mundo, con sus leyes, al que "pertenecen todos los que no son cristianos"

\begin{abstract}
"es el gobierno secular por la espada, que obliga a ser buenos y justos ante el mundo a aquellos que no quieren hacerse justos y piadosos para la vida eterna. Esta justicia la administra Dios mediante la espada. Y aunque no quiere retribuir esta justicia con la vida eterna, sí quiere que exista para mantener la paz entre los hombres y la recompensa con bienes temporales" 67.
\end{abstract}

Los dos reinos son necesarios, pero no deben confundirse, porque sólo el reino de Dios "hace piadosos" a los hombres, mientras el secular "crea la paz exterior e impide las malas obras", pero sin que ello implique que "nadie llega a ser verdaderamente bueno" ${ }^{\prime 6}$. La doctrina de los dos reinos pretende romper con la confusión proveniente de la Edad Media entre el territorio del alma y la fe y el que corresponde al mundo terrenal. Mediante la misma, Lutero quiere separar tajantemente la jurisdicción religiosa y la civil: "El gobierno secular tiene leyes que no afectan más que al cuerpo, a los bienes y a todas las cosas exteriores que hay en la tierra. Sobre las almas no puede ni quiera Dios dejar gobernar a nadie que no sea él mismo" ${ }^{6}$. Desde este punto de vista la guerra es una tarea encomendada a la autoridad secular en la que los verdaderos cristianos, que no la necesitan por sí mismos, deben colaborar con el máximo empeño por amor al prójimo, esto es, para evitar las injusticias de las que puedan ser víctimas los más débiles ${ }^{70}$. El recurso al organicismo sirve para justificar lo que se presenta como

${ }^{64}$ M. Lutero, "Sobre la autoridad secular: hasta dónde se le debe obediencia" (1523), en M. Lutero, Escritos políticos, estudio preliminar y traducción de J. Abellán, Madrid, Tecnos, 1990, pág. 28. Véase el estudio de J. Abellán, pág. XXV: "En los textos bíblicos se encuentra la clave para entender su pensamiento político y en ellos fundamenta Lutero su doctrina de los dos reinos, pieza central de su pensamiento y de su posición ante lo político".

${ }^{65}$ Ibídem, "Si los hombres de armas también pueden estar en gracia" (1526), en M. Lutero, Escritos políticos, ed. cit., pág. 134

66 "Sobre la autoridad secular: hasta dónde se le debe obediencia", pág. 30.

67 "Si los hombres de armas también pueden estar en gracia”, págs. 134-5.

68 "Sobre la autoridad secular: hasta dónde se le debe obediencia", pág. 31.

${ }^{69}$ Ibídem, pág. 44, y véase pág. 51.

70 Ibídem, pág. 34-5. 
una forma de cooperación social: “¿No es antinatural, por no decir anticristiano, que un miembro no ayude al otro, que no lo defienda de su ruina?"71.

Los verdaderos cristianos ponen sus ideales por encima de un mundo de intereses y ambiciones, pero eso no quiere decir que no tengan que desenvolverse en el mismo y convivir con otras personas que no han alcanzado ese privilegio. No se trata de la doctrina de la doble exigencia, una para aquellos que aspiren a la perfección máxima y otra para los que deben vivir en el mundo. Lutero rechazó esta interpretación del deber cristiano, que identificó como propia de los escolásticos ${ }^{72}$, con la misma convicción con la que rechaza el recurso a Sto. Tomás $^{73}$. Todos los cristianos están obligados al cumplimiento de las mismas exigencias, pero no todos han alcanzado a comprender el mensaje cristiano y asumirlo. Por eso, porque todavía muchas personas no se comportan como verdaderos cristianos, los que lo son no deben rechazar el servicio a los príncipes y la participación en la guerra cuando tiene como finalidad extender la justicia:

“en las palabras de Cristo citadas antes, Mateo 5, 39, que él enseña que los cristianos no deben tener entre ellos ningún derecho ni espada secular; sin embargo, no prohíbe servir a aquellos que tienen la espada secular y el derecho y ser súbditos de ellos sino que, más bien, como no los necesitas ni debes tenerlos, debes servir a aquellos que no han llegado tan alto como tú y todavía los necesitan" "74.

Renunciar a extirpar la injusticia y la maldad del mundo y confiar en que sería posible que se impusieran por sí mismos, sería una ingenuidad; sólo serviría para dejar el mundo en manos de los más desalmados, con el consiguiente perjuicio para la mayoría ${ }^{75}$. Incluso en el Antiguo Testamento no deja de encontrar Lutero,

71 "A la nobleza cristiana de la nación alemana acerca de la reforma de la condición cristiana" (1520), en M. Lutero, Escritos políticos, ed. cit., pág. 12.

72 "Sobre la autoridad secular: hasta dónde se le debe obediencia", pág. 22: los "sofistas de las universidades (...) han enseñado que Cristo no ordenó estos mandamientos, sino que sólo los aconsejó para los perfectos. (...) Su venenoso error se ha extendido a todo el mundo, de modo que todos consideran esta doctrina de Cristo como consejos para los perfectos y no como mandamientos obligatorios y comunes para todos los cristianos"; véase M. Lutero, On war against the Turk, http:// www.lutherdansk.dk/On $\% 20$ war $\% 20$ against $\% 20$ Islamic $\% 20$ reign $\% 20$ of $\% 20$ terror $/ 0 n \% 20$ war $\% 20$ against $\% 20$ Islamic\%20reign\%20of\%20terror1.htm, pág. 23 (Consulta 15.III.2014).

${ }^{73}$ D. R. Janz, Luther and Late Medieval Thomism: A Study in Theological Anthropology. Waterloo, Ontario. Wilfrid Laurier University Press, 1983, pág. 3: "Desde el siglo dieciséis, las teologías de Lutero y Santo Tomás parecen haber estado enfrentadas. En la visión de Lutero, Tomás era "la fuente y fundamento de toda herejía, error y obliteración del Evangelio"”.

74 "Sobre la autoridad secular: hasta dónde se le debe obediencia", pág. 34; On war against the Turk, págs. 15-8.

75 "Sobre la autoridad secular: hasta dónde se le debe obediencia", pág. 31: "Gobernar un país entero o el mundo con el Evangelio es como si un pastor reuniera en un mismo establo lobos, leones, águilas y corderos y los dejara ir y venir libremente entre ellos y les dijera: «Paced y sed buenos y pacíficos unos con otros, el establo está abierto, tenéis bastante pasto y no tenéis que tener miedo de los perros ni del cayado». Las ovejas, ciertamente, mantendrían la paz y se dejarían alimentar y gobernar pacíficamente, pero no vivirían mucho tiempo ni ningún animal sobreviviría a los demás".

Araucaria. Revista Iberoamericana de Filosofía, Política y Humanidades, año 16, n 32. Segundo semestre de 2014. Pp. 25-52. ISSN 1575-6823 e-ISSN 2340-2199 doi: 10.12795/araucaria.2014.i32.02 
a diferencia de Erasmo, una justificación de la práctica de la guerra entre los elegidos de Dios ${ }^{76}$. La razón es clara y también supone un planteamiento opuesto al erasmista: el alemán no aceptaba que la ley antigua hubiera sido derogada una vez que Cristo trajo la nueva: "Si alguien argumentase que el Antiguo Testamento está abolido y que no tiene ya validez, por lo que no se podrían proponer esos ejemplos a los cristianos, yo respondo que eso no es así"77.

Así pues, argumentándolo desde diferentes puntos de vista, el luteranismo sostuvo que mantener una postura ajena a las necesidades políticas y militares de las sociedades sería tanto como desentenderse de las necesidades de la convivencia, cuando los cristianos deben dar más ejemplo que nadie de su compromiso con ésta ${ }^{78}$.

Estas ideas no dejan lugar a dudas sobre la actitud ante la guerra del predicador alemán. Desde luego son las que desarrolló en la Guerra de los campesinos $^{79} \mathrm{y}$ tienen mucho que ver con su pésima opinión del pueblo ${ }^{80}$. Pero cuando se radicalizan hasta alcanzar su paroxismo es a propósito de la amenaza otomana $^{81}$. Concibe esta guerra como un enfrentamiento que no tendría límite alguno, porque se pelearía contra el turco "usando la fuerza física con gusto, golpeando, matando, asolando y provocando todo el daño posible con toda confianza" $"$.

Lutero no se detiene ante las críticas pacifistas que encontraban en el mensaje evangélico su inspiración contra la guerra. Les hace frente apelando a la imposibilidad de que Cristo desempeñara todas las tareas:

"Si dices: ¿por qué Cristo y los apóstoles no llevaron la espada?, yo respondo: dime por qué tampoco tomó mujer o no se hizo zapatero o sastre. ¿No iba a ser buena una profesión o un oficio por el hecho de que Cristo no los haya desempeñado él mismo? ¿Dónde iban a parar todos los oficios y profesiones, excepto

${ }^{76}$ Ibidem, pág. 35-6.

77 Ibídem, pág. 36.

${ }^{78}$ Ibídem, págs. 38-9: "No sería en absoluto cristiano decir que existen servicios a Dios que un cristiano no debiera o tuviera que hacer, siendo así que para el servicio a Dios nadie es tan apto como el cristiano y, en verdad, sería muy bueno y necesario que todos los príncipes fuesen buenos y auténticos cristianos. La espada y el poder, como servicio especial a Dios, corresponden al cristiano con preferencia a todos los demás hombres en la tierra".

79 "Exhortación a la paz en contestación a los doce artículos del campesinado de Suabia" (1525); "Contra las bandas ladronas y asesinas de los campesinos" (1525), y "Carta sobre el duro librito contra los campesinos" (1525), en M. Lutero, Escritos politicos, ed. cit.

80 "Si los hombres de armas también pueden estar en gracia", págs. 140-1: "No hay que hacer mucho caso al pueblo, pues por lo demás le gusta alborotar, y es más equitativo negarle diez varas que concederle la anchura de una mano o, incluso, de un dedo; es mejor que los tiranos le hagan cien injusticias a que el pueblo le haga una sola a los tiranos. Si hay que sufrir injusticia, es de preferir sufrirla de la autoridad a que la autoridad la sufra de sus súbditos. El pueblo no tiene ni conoce la medida y en cada individuo se esconden más de cinco tiranos. Es mejor sufrir injusticia de un solo tirano, es decir, de la autoridad, que sufrirla de innumerables tiranos, es decir, del pueblo".

${ }^{81}$ G. W. Forell, Luther and the War against the Turks, "Church History", 14 (1945), págs. 256-71.

${ }^{82}$ M. Lutero, "Alegato contra los turcos" (1529, posterior al levantamiento del sitio de Viena), en Obras, versión castellana de C. Witthaus, Buenos Aires, Paidós, 1974, pág. 218. 
el de predicador que fue el único que ejerció? Cristo ha ejercido su oficio y su profesión, pero no por ello ha condenado ninguna otra profesión"83.

A pesar de estos testimonios, numerosos pensadores criticaron el pacifismo luterano e identificaron como opuesta a la guerra su postura. Ésta es una razón más para su frecuente identificación, sobre todo en Italia, con Erasmo ${ }^{84}$. Tal malentendido se establece desde los primeros momentos de su disidencia, cuando Lutero hizo de la oposición a financiar la cruzada, con su secuela de indulgencias y subordinación de la actividad espiritual al provecho económico, un motivo para denunciar la corrupción de Roma ${ }^{85}$. Esta postura se manifestó en su primera aproximación a la cuestión en las Resolutiones disputationum de indulgentiarum virtute, de 1518; comentando la quinta de las 95 tesis de su Disputación acerca de la determinación del valor de las indulgencias (1517), relativa a la capacidad de los pontífices para perdonar las sentencias divinas, Lutero no dejaba de mostrar una cierta oposición a la guerra:

\begin{abstract}
"Muchos, sin embargo, incluso entre los "peces gordos" de la Iglesia, no sueñan ahora con otra cosa que la guerra contra los turcos. Quieren luchar, no contra las iniquidades, sino contra el azote de la iniquidad y por lo tanto se oponen a Dios, que dice que a través de este azote él mismo nos castiga por nuestras iniquidades, porque nosotros no nos castigamos por ellas" $"$.
\end{abstract}

Desde Roma, el papa León X inició el proceso de excomunión del alemán al promulgar el 15 de junio de 1520 la bula Exsurge Domine. En la misma se exigía la retractación de los "perniciosos" errores extraídos en su mayor parte de las 95 Tesis; uno de los que se le atribuían era que había afirmado que "ir a la guerra contra los turcos es resistir a Dios, que castiga nuestros pecados a través de ellos"87. Con ello, lo que era secundario en el comentario de Lutero, que cuestionaba el poder de remisión de los pecados por los papas, pasa a un primer plano y se convierte en un juicio de carácter sustantivo sobre la guerra contra el turco ${ }^{88}$.

83 "Sobre la autoridad secular: hasta dónde se le debe obediencia", pág. 39.

${ }^{84}$ S. Seidel Menchi, Erasmo in Italia, 1520-1580, Torino, Bollati Boringhieri, 1987, págs. 41-67, y E. Rummel, Erasmus and his catholic critics. I. 1515-1522. II.1523-1536; Nieuwkoop, De Graaf Publishers, 1989, II, págs. 150-1.

${ }^{85}$ H. Buchanan, Luther and the Turks 1519-1529, "Archiv für Reformationsgeschichte”, XLVII (1956), págs. 145-60; K. M. Setton, Lutheranism and the Turkish peril, "Balkan Studies”, III (1962), págs. 133-68; R. O. Smith, Luther, the Turks, and Islam, "Currents in Theology and Mission" (oct. 2007), en http://findarticles. $\mathrm{com} / \mathrm{p} /$ articles/mi m0MDO/is 5 34/ai n21053788/?tag=content;coll (Consulta 15.III.2011).

${ }_{86}$ M. Lutero, Explanation of the Ninety-five Theses, en Luther's Works, 31, págs. 79-252 (Philadelphia: Fortress and St. Louis. Concordia, 1955-1986; reproducida en http://www.reocities. com/united_in_christ_3in1/95explained.pdf, pág. 5 (Consulta 16.III.2011).

${ }^{87}$ Cito la bula por la edición reproducida en http://www.papalencyclicals.net/Leo10/110exdom. htm, error 34 (Consulta 16.III.2011).

${ }^{88}$ H. J. Hillerbrand, Martin Luther and the Bull "Exsurge Domine”, "Theological Studies", $30: 1$ (1969 Mar.), pág.111.

Araucaria. Revista Iberoamericana de Filosofía, Política y Humanidades, año 16, n 32. Segundo semestre de 2014. Pp. 25-52. ISSN 1575-6823 e-ISSN 2340-2199 doi: 10.12795/araucaria.2014.i32.02 
A partir de este momento, un halo de confusión envolvió la opinión de Lutero. Su pacifismo, basado en los textos citados, se convirtió en un dogma del que resultó poco menos que imposible salir, al menos entre pensadores católicos ${ }^{89}$, tanto escolásticos ${ }^{90}$ como humanistas $^{91}$. Se comprende desde esta perspectiva, que se viera afinidad en las posturas de Erasmo y Lutero, y que desde el bando católico se reprochara al holandés, más que la intención última que pudiera albergar con su escritura, los malentendidos que alimentaba de cara a un público incapaz de sutiles distinciones. Se consideraba, en consecuencia, que la seducción que ejercía su literatura podría resultar fatal para crear nuevas formas de opinión que alimentasen a los luteranos ${ }^{92}$.

Puede admitirse que el pacifismo de Lutero no fue sólo un artificio del bando católico, sino que fue alimentado por su propia actitud, pues "la fuente de sus puntos de vista [sobre los turcos] es a menudo poco clara o incluso extrañamente contradictoria" ${ }^{\prime 3}$. No debe sorprender que se hable del "cambiante Lutero" 94 , que en su guerra contra el papado no tiene reparo en presentar a los pontífices como verdaderos enemigos del Evangelio, mucho más peligrosos que el turco ${ }^{95}$. Más adelante, aunque modificará su postura hasta unirse a los que alientan la guerra contra Solimán, no dejará de repetir expresiones similares ${ }^{96}$.

Al margen de este rechazo inicial de la guerra contra el turco, que no implica en cualquier caso un rechazo a la guerra sino al enfrentamiento contra el ejército de Solimán en las circunstancias del momento, no hay en Lutero sombra alguna de pacifismo. En ausencia de una teoría de la guerra que fuera más

${ }^{89}$ H. Mechoulan, Le pacifisme de Luther ou le poids d'une bulle, "Mélanges de la Casa de Velázquez", 9 (1973), págs. 723-9, atribuye exclusivamente a la bula el pacifismo del reformador, pero Lutero mismo reconoce al inicio de On war against the Turk, págs. 1-5, su oposición a la guerra en las circunstancias de 1518.

${ }^{90}$ F. de Vitoria, De iure belli, pág. 101: "Lutero, que nada dejó por contaminar, niega ser lícito a los cristianos tomar las armas ni siquiera contra los turcos”; F. Suárez, Guerra. Intervención. Paz internacional. Estudio, traducción y notas por L. Pereña Vicente. Madrid, Espasa-Calpe, 1956, págs. 51-2: "Cristo y los apóstoles condenaron toda violencia. En su libro sobre el Príncipe Cristiano trae Erasmo estas palabras; en el tratado de los Adagios defiende que no es lícito a los cristianos hacer la guerra después que mandó Cristo envainar la espada. También Lutero cayó en el mismo error al condenar la guerra contra los turcos. Porque, decía, no se puede hacer resistencia a la voluntad de Dio, que manda estos castigos".

${ }^{91}$ Erasmo, "Utilísima consulta acerca de la declaración de guerra al turco", págs. 1008, 1009 y 1016.

92 S. Seidel Menchi, Erasmo in Italia, 1520-1580, págs. 43 y 52-3.

93 S. Henrich y J. L. Boyce, Martin Luther - Translations of Two Prefaces on Islam: Preface to the Libellus de ritu et moribus Turcorum (1530), and Preface to Bibliander's Edition of the Qur'ān (1543), "Word \& World", XVI: 2 (1996), pág. 253.

${ }^{94}$ T. Egido, Introducción a M. Lutero, Obras, Salamanca, Sígueme, 2006, pág.54; véase Q. Skinner, Los fundamentos del pensamiento político moderno. II. La Reforma. México, FCE, 1986 (1978), pág. 24.

${ }_{95}$ Tomo la cita de Lutero de la citada Introducción de T. Egido, p.54: “QQué mal hace el turco? A fin de cuentas conquista un país, pero deja que todos sigan con sus creencias. Diez veces peor que el de los turcos es el régimen del papa. La mejor forma de combatir a los turcos es predicarles el evangelio" (Bulla coenae Domini, WA, 8, 798 y ss.).

${ }^{96} \mathrm{Si}$ no existiesen otros testimonios, bastaría ver las manifestaciones sobre los turcos que recoge el Índice temático de la edición de T. Egido para confirmarlo. 
allá de la dialéctica del castigo y la represión ante cualquier amenaza al orden establecido, parece optar por adherirse a la teoría de la guerra justa:

\begin{abstract}
“¿qué es una guerra justa, sino castigar a los malhechores y mantener la paz? Cuando se castiga a un ladrón, a un asesino o a un adúltero se está castigando a un malhechor individual. Pero cuando se hace la guerra justamente se castiga de una vez a un gran número de malhechores que hacen un daño tan grande como grande sea el número de ellos. Si una obra de la espada es buena y recta, lo son también todas las demás"97.
\end{abstract}

Pero, a pesar de esta justificación ocasional que, en ocasiones, reduce a mera guerra defensiva ${ }^{98}$, a Lutero no le hace falta una teoría de tanta raigambre como la de la guerra justa para justificar su apoyo a la guerra: fueron numerosos los escritos en los que se mostró favorable al uso de la fuerza, aunque, eso sí, siempre que su empleo fuera dirigido por la autoridad secular y sólo en caso de necesidad. Así, puede citarse: "cuando los enemigos asaltan una ciudad el honor y el agradecimiento lo gana el primero que reúne a los demás" "99; también es significativo: "es voluntad de Dios que se emplee la espada y el derecho seculares para el castigo de los malos y para la protección de los buenos" y, sobre todo:

\begin{abstract}
"los súbditos están obligados a seguirle [al príncipe] y a arriesgar sus cuerpos y sus bienes. Pues en este caso uno debe, por amor a los demás, arriesgar sus bienes y a sí mismo. En semejante guerra es cristiano y obra del amor el ahorcar sin temor a los enemigos, saquearlos y quemarlos y hacer todo lo que pueda perjudicarles hasta que se les haya vencido según el curso de la guerra (con la excepción de cuidarse de pecar, de deshonrar a las mujeres y a las doncellas)"100.
\end{abstract}

Estas manifestaciones generales no establecen ninguna excepción, pero, por si no fuera suficiente, Lutero no dejó de expresarse en la misma dirección en Sobre la guerra contra el turco ${ }^{101}$, haciendo al ejército de Solimán blanco de sus ataques. Sin embargo, también en ese mismo escrito, volvía a insistir en que en que dicha guerra debe ser apoyada por sus seguidores siempre que quedase claro que "el emperador no es la cabeza de la Cristiandad o defensor del evangelio o la fe" $" 102$.

\footnotetext{
97 "Si los hombres de armas también pueden estar en gracia”, pág. 133.

${ }^{98}$ Ibídem, págs. 154-5.

${ }_{99}$ M. Lutero, "A la nobleza cristiana de la nación alemana acerca de la reforma de la condición cristiana" (1520), en Escritos políticos, ed. cit., págs. 18-9.

${ }^{100}$ Ibídem, "Sobre la autoridad secular: hasta dónde se le debe obediencia" (1523), pp. 27 y 61; etc.

${ }^{101}$ La obra lleva una dedicatoria del 9 de octubre de 1528 (On war against the Turk, p. 2), aunque se imprimió por Hans Weiss en Wittenberg el 16 de abril de 1529.

${ }^{102}$ On war against the Turk, pág. 15. Véase A. S. Francisco, Martin Luther and Islam. A Study in Sixteenth-Century Polemics and Apologetics, Leiden-Boston, Brill, 2007, págs. 74-5.
} 


\section{El humanismo cívico y la guerra}

Aunque el pensamiento de Maquiavelo se inscribe dentro de la tradición del humanismo cívico, que exalta la virtud militar ${ }^{103}$, tampoco hay en éste una teoría de la guerra propiamente dicha, sino una consideración de la guerra como política en acción. La mención que aparece en El príncipe $e^{104}$ a la justicia de la guerra, procedente de Tito Livio ${ }^{105}$, no es una apelación a la teoría de la guerra justa sino, más bien, una llamada de atención a la justificación de cualquier acción armada ${ }^{106}$. Maquiavelo nunca albergó dudas de que la salvación de la patria justifica cualquier acción moral o inmoral ${ }^{107}$, lo que no admitiría ningún teórico de la guerra justa. A pesar de su título, tampoco en Del arte de la guerra aparece una teoría propiamente dicha, sino una serie de consejos y propuestas que poseen más un carácter técnico sobre cuanto implica una guerra que un desarrollo de aquel tipo. Sin embargo, se trate de una propuesta de reforma militar, de un análisis del funcionamiento de una república o de la mejor manera de obtener y mantener el poder en un principado, en el florentino aparece siempre la guerra ${ }^{108}$. Si en Maquiavelo se da una consideración política de todo lo humano ${ }^{109}$, la guerra no puede ser ajena a la misma.

La visión conflictiva de la realidad que se desprende tanto de la concepción antropológica $^{110}$ de Maquiavelo como de la propia tendencia al dominio y la conquista que atribuye a gobernantes ${ }^{111}$ y sociedades ${ }^{112}$, convierte la guerra en

${ }^{103}$ D. R. Kelley, Renaissance Humanism, ed. cit., pág. 53: "Dos consideraciones tienen que hacerse acerca de la tradición retórica del "humanismo cívico" y la idealizada tradición del "humanismo civil" celebrado por estudiosos contemporáneos. Una es la tendencia a olvidar la cara oscura del humanismo cívico (como le pareció a Erasmo y otros), que es la exaltación de la virtud militar”.

104 N. Maquiavelo, El príncipe, trad. de Á. Cardona de Gibert, Barcelona, Bruguera, 1978, cap. XXVI, párrafo 3, pág. 182 .

${ }^{105}$ Historia de Roma desde su fundación. Libros VIII-X, trad. y notas de J. A. Villar Vidal, Madrid, Gredos, 1990, IX, 1, pág. 98: "La guerra... es justa cuando es una necesidad, y las armas legítimas para aquellos a los que no se les deja más esperanza que las armas".

106 Véase R. del Águila y S. Chaparro, La república de Maquiavelo, Madrid, Tecnos, 2006, pág. 168; C. Rousseau, "La doctrine de la guerre de Machiavel", en N. Bobbio et al., La guerre et ses théories. París, PUF, 1970, pág. 24: "l'opposition traditionnelle entre guerre juste et guerre injuste apparaît ainsi comme dépourvue de sens pour Machiavel".

${ }_{107}$ N. Maquiavelo, Discursos sobre la primera década de Tito Livio, trad., introd.. y notas de A. Martínez Arancón, Madrid, Alianza, 2005, libro III, parágrafo 41, pág. 433.

108 M. Carrera Díaz, "Estudio preliminar" a N. Maquiavelo, Del arte de la guerra; estudio preliminar, trad. y notas de..., Madrid, Tecnos, 1988, pág. XVI: "Maquiavelo no separa la milicia, y en definitiva la guerra, de la política".

109 M. Á. Granada, Cosmología, religión y política en el Renacimiento: Ficino, Savonarola, Pomponazzi, Maquiavelo, Barcelona, Anthropos, 1988, pág. 32. Véase ibídem, págs. 218-45.

${ }^{110}$ Discursos sobre la primera década de Tito Livio, I, 3, 40: "es necesario que quien dispone una república y ordena sus leyes presuponga que todos los hombres son malos, y que pondrán en práctica sus perversas ideas siempre que se les presente la ocasión de hacerlo libremente". Véase Discursos, I, 29, 109; I, 37, 126-7 y II, Pr., 190; El príncipe XVII.2, 148.

${ }^{111}$ El príncipe, XVIII.3 y 4, 151-2.

112 Discursos sobre la primera década de Tito Livio, I, 29, 110: “teniendo una ciudad que vive 
un elemento ineludible de la convivencia. Asimismo, la inspiración clásica que tantas veces le servía de guía, especialmente a través del ejemplo de los romanos, conducía a Maquiavelo a pensar en la guerra como el complemento inevitable de la estabilidad de la sociedad. Todo ello le sirve al florentino para descartar cualquier tentación de alejarse del enfrentamiento armado, "porque todo cuanto se establece en una sociedad para el bien común de los hombres, todas las instituciones que regulan la vida en el temor de Dios y de la ley resultarían vanas si no se dispusiera de mecanismos que las defendiesen"113. Esto es, en un universo dominado por la guerra, la pretensión de evitarla, rechazarla o ignorar su posibilidad sólo conduce a dar ventaja a otros ${ }^{114}$. Vista desde esta perspectiva, la guerra alcanza un protagonismo que sobrepasa con mucho el de mero apéndice de la política para pasar a convertirse en su cara armada.

La guerra tiene una presencia permanente tanto dentro como fuera de la comunidad. En el interior de ésta, los enfrentamientos civiles provocan cambios continuos en las formas de gobierno ${ }^{115}$, y ponen en peligro la misma independencia de la república. Lo deseable sería evitar las querellas civiles, pero dada la ambición de los hombres y su tendencia a imponerse unos sobre otros, es inevitable el conflicto ${ }^{116}$. En ocasiones, como en la República romana éste pudo tener efectos beneficiosos ${ }^{117}$, contribuyendo a la perfección de su gobierno; pero lo habitual es que el deseo permanente de todo y la imposibilidad de alcanzarlo por parte de los ciudadanos acabe llevando a la sociedad afectada a la ruina ${ }^{118}$. No cabe, por tanto, poner freno a un deseo que constituye la manera de ser de los hombres; el único recurso es desviar ese impulso hacia otros objetivos. Aquí cumple su función la guerra fuera de la comunidad.

Cuando se dirige hacia el exterior de la república, la guerra refuerza la unión entre los ciudadanos ${ }^{119}$ y contribuye a que los más virtuosos se pongan al frente de los gobiernos ${ }^{120}$, por lo que nada más saludable que prepararse para la misma. Desarrollar lo que requiere la guerra, el orden y la disciplina militar es lo mejor que puede hacer el príncipe si quiere mantener su poder ${ }^{121}$. Este pensamiento es el que parece inspirar a Maquiavelo cuando organiza las milicias de Florencia y cuando quiere construir un ejército de ciudadanos, que

en libertad dos fines: uno, conquistar nuevos territorios, y el otro, mantenerse libre, conviene que no cometa equivocaciones, por exceso de amor, en ninguno de ellos".

${ }_{113}$ Del arte de la guerra, Proemio, 6.

114 El príncipe, III.8 y 13, 98 y 100.

115 Discursos sobre la primera década de Tito Livio, I, 2, 35-7.

${ }^{116}$ Ibidem, I, 46, 148.

117 Ibidem, I, 2, 39.

118 Ibidem, I, 37, 127.

119 Ibidem, II, 25, 280.

120 Ibidem, III, 16, 370.

${ }^{121}$ El príncipe, XIV.1, 140; véase Del arte de la guerra, I, 14. 
todavía reivindica en Del arte de la guerra ${ }^{122}$; y no sería erróneo apreciar ese mismo empeño tras la redacción de ese libro. Quien es experto en el arte con las armas puede conquistar un estado, mientras que el que carece de esa habilidad puede llegar a perderlo. Es fundamental, por tanto, la pericia en la guerra.

Ese principio se hace más evidente atendiendo a las circunstancias en las que se desenvolvía Maquiavelo. Si no eran suficientes los problemas internos de Florencia, el contexto de la época obligaba a tener en cuenta la necesidad de recurrir o verse inmerso en la guerra, tanto para defenderse de cualquier enemigo como para sobrevivir en un mundo en el que a la trama compleja de los principados y repúblicas italianas se habían añadido, con una fuerza muy superior, las potencias de la época. Tanto los intereses de Francia y España como la propia dinámica de las comunidades de la península itálica estaban demasiado ligados entre sí como para que fuera posible permanecer al margen. Fuera buscada por sí misma o como reacción a la ambición de los demás, la guerra era una realidad de la que era imposible escapar ${ }^{123}$. Sólo cabía intentar manejarse en ella de la mejor manera. La posibilidad de navegar sin hundirse en ese mar que muchas veces parecía ser un océano enseñoreado por la fortuna pasaba por hacer uso de una virtù que se le opusiera y encauzara ${ }^{124}$; esa virtù encuentra su mejor expresión en la habilidad militar de la comunidad.

La presencia de esa virtù es la que puede permitir a la comunidad librarse de esos ejércitos de mercenarios cuya entrega a la lucha es tan poco de fiar $^{125}$. En ellos concentra Maquiavelo sus críticas tanto por su apego al dinero como por su escasa fidelidad y su tendencia a generar todo tipo de desórdenes ${ }^{126}$. Depender de los ejércitos de mercenarios es tanto como dejarse llevar por la fortuna, lo que equivale a encaminarse al desastre ${ }^{127}$. Por eso, no duda Maquiavelo en señalarlos como una de las causas principales de la ruina de Italia $^{128}$. La alternativa a ese ejército de mercenarios con la que sueña Maquiavelo es una milicia ciudadana, un auténtico cuerpo armado de ciudadanos comprometidos con su ciudad ${ }^{129}$. Incluso llega a describir el aspecto que deberían tener esos milicianos, acercándolos más al ideal apolíneo de las representaciones clásicas ${ }^{130}$, que a la forma real que podían tener hombres que

\footnotetext{
${ }^{122}$ Del arte de la guerra, I, 27.

123 Discursos sobre la primera década de Tito Livio, II, 19, 255; véase I, 6, 50-51.

${ }^{124}$ El príncipe, XXV.3, 179: la fortuna "demuestra su dominio cuando no encuentra una virtud que se le resista".

${ }^{125}$ Discursos sobre la primera década de Tito Livio, I, 4, 41.

${ }_{126}$ El príncipe, XII.2, 131-32; véase Del arte de la guerra, I, 16.

${ }_{127}$ Discursos sobre la primera década de Tito Livio, II, 20, 259-61; El príncipe, XIII.1, 136.

${ }^{128}$ El príncipe, XII.3, 132; véase XXV.3, 179.

129 Ibídem, XII.5, 133; véase Discursos sobre la primera década de Tito Livio, I, 43, 143 y Del arte de la guerra, I, 26.

${ }^{130}$ Del arte de la guerra, I, 32: "Los tratadistas dicen que el soldado debe tener los ojos vivos y alegres, el cuello vigoroso, el pecho ancho, los brazos musculosos, los dedos largos, poco vientre, las caderas robustas, pies y piernas delgados".
} 
viven de sus negocios y actividades y sólo ocasionalmente se ocupan de las $\operatorname{armas}^{131}$. A pesar de la importancia que otorga a la guerra, la admiración de Maquiavelo hacia las técnicas y estrategias militares de los antiguos griegos y, sobre todo, romanos, le impide reconocer en más ocasiones de las debidas las ventajas que imponían las nuevas formas, armas y organización que venía imponiendo el Renacimiento ${ }^{132}$; aunque resulte difícil poder hacer reproche alguno a Maquiavelo en su visión de la guerra como fenómeno político, el mimetismo hacia los modelos militares antiguos no deja de ser un obstáculo para su comprensión técnica del asunto ${ }^{133}$.

En cualquier caso, para Maquiavelo lo importante es que los hombres que van a luchar se sometan a una disciplina que les dote de unidad y los convierta en un único cuerpo. Prepararse en tiempo de paz para la guerra es lo mejor que se puede hacer para evitar verse sorprendido cuando llega la ocasión de usar las $\operatorname{armas}^{134}$, y un príncipe que mantenga esta precaución estará en mucha mejor disposición de mantener su reino que si se entrega a "las delicias de la vida"135. Incluso un conocimiento teórico como el que proporciona la historia puede ser útil para aprender del pasado porque nos dice, entre otras muchas cosas, cómo organizar el ejército y llevar a cabo la guerra ${ }^{136}$. Dada la inmutabilidad de la naturaleza humana ${ }^{137}$, ese aprendizaje es el mejor remedio para saber cómo actuar en el presente.

La actitud ante la guerra de Maquiavelo, que equivale a una integración y normalización de la misma en la vida cotidiana, puede considerarse el caso más representativo de confianza de un pensador del Renacimiento en la misma como método de resolución de conflictos. La tradición a la que da lugar no excluye estas ideas ${ }^{138}$.

Con Maquiavelo se acaba este repaso a la idea de la guerra entre algunos de los hombres más representativos de la primera mitad del siglo XVI. Sería necesario incluir algunos más, efectuar un trabajo comparativo mucho más detallado que el apenas esbozado aquí y mostrar sus posteriores líneas de desarrollo, que se

\footnotetext{
131 Ibidem, I, 31.

${ }^{132}$ M. Carrera Díaz, "Estudio preliminar" a N. Maquiavelo, Del arte de la guerra, págs. XXIIIXXVI.

133 A. Campillo, La fuerza de la razón. Guerra, Estado y ciencia en el Renacimiento. Murcia, Universidad de Murcia, 2008, págs. 46-8.

${ }^{134}$ Discursos sobre la primera década de Tito Livio, I, 21, 96.

135 El príncipe, XIV.1, 140.

${ }^{136}$ Discursos sobre la primera década de Tito Livio, I, Proemio, 28: "cuando se trata de ordenar la república, de mantener el estado, gobernar el reino, organizar el ejército y llevar a cabo la guerra, juzgar a los súbditos o acrecentar el imperio, no se encuentra príncipe ni república que recurra a los ejemplos de los antiguos. Esto procede, en mi opinión, no tanto de la debilidad a que ha conducido al mundo la presente religión, o del mal que el ocio y la ambición han causado en muchas provincias y ciudades cristianas, como de no tener verdadero conocimiento de la historia, y de no extraer, al leerla, su sentido, ni gozar del sabor que encierra”. Véase El príncipe, XIV.5, 142.

137 Discursos sobre la primera década de Tito Livio, I, Proemio, 28-29.

138 J.G.A. Pocock, El momento maquiavélico. El pensamiento político florentino y la tradición republicana. Madrid, Tecnos, 2002 (1975).
} 
entrecruzan bastante, para lograr un panorama realmente representativo de la época. Ante la imposibilidad de hacerlo en este lugar, sólo quiero destacar una conclusión: durante el período reseñado, la guerra (el recurso a la misma, su oportunidad, su vínculo con la religión, justicia, inevitabilidad, etc.) es un asunto tan importante y las consecuencias de las opiniones sobre la misma tan decisivas en tantos otros aspectos, que puede servir como eje para definir las posturas políticas de los hombres de la época con más precisión y claridad que ningún otro tema. 


\section{Referencias bibliográficas}

\section{A. Fuentes primarias}

Erasmo, Adagios del poder y de la guerra y Teoría del adagio, ed. de R. Puig, Madrid, Alianza., 2008.

—, "El 'Antipolemos', refutación de los motivos oficiales de la guerra", en Adagios del poder y de la guerra y Teoría del adagio, pp. 246-50.

—, "La guerra atrae a quienes no la han vivido" (Dulce bellum inexpertis), en Adagios del poder y de la guerra y Teoría del adagio.

—, "Los silenos de Alcibíades", en Adagios del poder y de la guerra y Teoría del adagio.

—, "Utilísima consulta acerca de la declaración de guerra al turco" (1530), en Erasmo, Obras escogidas, ed. de L. Riber, Madrid, Aguilar, 1964.

—, Educación del príncipe cristiano, est. Prel. de P. Jiménez; trad. de P. Jiménez y A. Martín, Madrid, Tecnos, 1996.

—, El Enquiridion o Manual del caballero cristiano, ed. de D. Alonso, pról.. de M. Bataillon, y La Paráclesis o Exhortación al estudio de las letras divinas, ed. y prólogo de D. Alonso (Traducciones españolas del siglo XVI); Madrid, 1971 (Revista de Filología Española, Anejo $\mathrm{XVI}$ ).

—, Elogio de la locura, int., trad. y notas de P. Rodríguez, Madrid, Alianza Edit., 2008.

Exurge domine, en http://www.papalencyclicals.net/Leo10/110exdom.htm (Consulta 16.III.2011).

Livio, Tito, Historia de Roma desde su fundación. Libros VIII-X, trad. y notas de J. A. Villar, Madrid, Gredos, 1990.

Lutero, M., "A la nobleza cristiana de la nación alemana acerca de la reforma de la condición cristiana" (1520), en M. Lutero, Escritos políticos.

- "A la nobleza cristiana de la nación alemana acerca de la reforma de la condición cristiana" (1520), en Escritos políticos.

—, "Alegato contra los turcos" (1529), en Obras, trad. de C. Witthaus, Buenos Aires, Paidós, 1974.

—, "Exhortación a la paz en contestación a los doce artículos del campesinado de Suabia" (1525); "Contra las bandas ladronas y asesinas de los campesinos" (1525), y "Carta sobre el duro librito contra los campesinos" (1525), en M. Lutero, Escritos políticos.

—, "Si los hombres de armas también pueden estar en gracia" (1526), en M. Lutero, Escritos politicos.

—, "Sobre la autoridad secular: hasta dónde se le debe obediencia" (1523), en M.

Lutero, Escritos políticos.

—, Escritos políticos, est. prel. y trad. de J. Abellán, Madrid, Tecnos, 1990.

- Explanation of the Ninety-five Theses, en Luther's Works, 31, págs. 79-

Araucaria. Revista Iberoamericana de Filosofía, Política y Humanidades, año 16, $\mathrm{n}^{\circ} 32$. Segundo semestre de 2014. Pp. 25-52. ISSN 1575-6823 e-ISSN 2340-2199 doi: 10.12795/araucaria.2014.i32.02 
252 (Philadelphia: Fortress and St. Louis. Concordia, 19551986; reproducida en http://www.reocities.com/united in christ 3in1/95explained.pdf (Consulta 16.III.2011).

—, Obras, intr. de T. Egido, Salamanca, Sígueme, 2006.

-, On war against the Turk, http://www.lutherdansk.dk/On\%20war\%20 against $\% 20$ Islamic $\% 20$ reign $\% 20$ of $\% 20$ terror $/ 0 n \% 20 \mathrm{war} \% 20$ against $\% 20$ Islamic\%20reign\%20of\%20terror1.htm, (Consulta 15.III.2014).

Maquiavelo, N., Del arte de la guerra; est. prel., trad. y notas de M. Carrera, Madrid, Tecnos, 1988.

—, Discursos sobre la primera década de Tito Livio, trad., introd. y notas de A. Martínez, Madrid, Alianza, 2005.

—, El príncipe, trad. de Á. Cardona, Barcelona, Bruguera, 1978.

Sepúlveda, J. Ginés de, Obras completas VI. Gonzalo, diálogo sobre la apetencia de gloria, introducción, edición crítica y traducción de J. J. Valverde Abril, Excmo. Ayuntamiento de Pozoblanco, 2001.

-, Obras completas VII. Exhortación a Carlos V. Edición crítica, traducción e introducción filológica de J. M. Rodríguez Peregrina. Introducción histórica de B. Cuart Moner. Excmo. Ayuntamiento de Pozoblanco, 2003, pág. 334.

Suárez, F., Guerra. Intervención. Paz internacional. Estudio, traducción y notas por L. Pereña Vicente. Madrid, Espasa-Calpe, 1956.

Vitoria, F. de, De potestate civili, en Obras. Relecciones teológicas, ed. T. Urdánoz, Madrid, BAC, 1960.

—, Relectio de indis, ed. L. Pereña, Madrid, CHP-CSIC, 1967.

—, Relectio de iure belli, ed. L. Pereña, Madrid, CHP-CSIC, 1981.

—, "De la insolidaridad de Europa y de la guerra contra el turco" (1526), pp. 39-61, y "De la condición de los cristianos bajo el turco" (1526), pp. 63-74, en J. L. Vives, Obras Completas, II; trad., comentarios y notas de L. Riber; Madrid, M. Aguilar - Generalitat Valenciana, 1948 (1992).

\section{B. Estudios}

Águila, R. del, y Chaparro, S., La república de Maquiavelo, Madrid, Tecnos, 2006.

Bataillon, M., "Un extremo del irenismo erasmiano en el adagio «Bellum»" (1969), en M. Bataillon, Erasmo y el erasmismo, trad. de C. Pujol, Barcelona, Crítica, 1983, págs. 64-79.

Bense, W.F., Paris Theologians on War and Peace, 1521-1529, "Church History", 41(1972) págs.168-85.

Buchanan, H., Luther and the Turks 1519-1529, "Archiv für Reformationsgeschichte", XLVII (1956), págs. 145-60. 
Campillo, A., La fuerza de la razón. Guerra, Estado y ciencia en el Renacimiento. Murcia, Universidad de Murcia, 2008.

Castilla Urbano, F., El pensamiento de Francisco de Vitoria. Filosofía política e indio americano, Barcelona, Anthropos, 1992.

Fernández Santamaría, J. A., Erasmus on the just war, "Journal of the History of the Ideas", XXXIV (1973), págs. 209-26.

Fernández Santamaría, J.A., El estado, la guerra y la paz. El pensamiento político español en el Renacimiento, 1516-1559. Madrid, Akal, 1988.

Fernández Santamaría, J. A., Juan Ginés de Sepúlveda: la guerra en el pensamiento politico del Renacimiento. Madrid, C.E.P. y C., 2007.

Forell, G. W., Luther and the War against the Turks, "Church History”, 14 (1945), págs. 256-71.

Francisco, A. S., Martin Luther and Islam. A Study in Sixteenth-Century Polemics and Apologetics, Leiden-Boston, Brill, 2007.

George, E. V., "Juan Luis Vives De Europea dissidiis et bello Turcico: Its Place in the 1526 Ensemble", J. F. Alcina et al. (eds.), Acta Conventus NeoLatini Bariensis, Tempe, 1998, pp. 259-266.

Granada, M. Á., Cosmología, religión y política en el Renacimiento: Ficino, Savonarola, Pomponazzi, Maquiavelo, Barcelona, Anthropos, 1988.

Henrich, S., y Boyce, J. L., Martin Luther - Translations of Two Prefaces on Islam: Preface to the Libellus de ritu et moribus Turcorum (1530), and Preface to Bibliander's Edition of the Qur'ān (1543), "Word \& World", XVI: 2 (1996).

Hillerbrand, H. J., Martin Luther and the Bull "Exsurge Domine", "Theological Studies", 30: 1 (1969 Mar.).

Janz, D. R., Luther and Late Medieval Thomism: A Study in Theological Anthropology. Waterloo, Ontario. Wilfrid Laurier University Press, 1983.

Kelley, D. R., Renaissance Humanism, Boston, Twayne Publishers, 1991.

Margolin, J.-C., "Conscience européenne et réaction á la menace turque d'après le «De dissidiis Europae et bello turcico» de Vives (1526)", A. Buck (ed.), Juan Luis Vives; Hamburg, Ernst Hanswedell et co., 1982, pp. 107-40.

Margolin, J.-C., Guerre et paix dans la pensée d'Érasme, introduction, choix de textes, commentaires et notes par... ; Paris, Aubier Montaigne, 1973.

Mechoulan, H., Le pacifisme de Luther ou le poids d'une bulle, "Mélanges de la Casa de Velázquez", 9 (1973), págs. 723-9.

Musto, R. G., "Just Wars and Evil Empires: Erasmus and the Turks", en J. Monfasani y R. G. Musto (eds.), Renaissance society and culture: essays in honor of E. F. Rice, Jr., New York, Italica Press, 1991, págs. 197-216.

Patrides, C. A., 'The Bloody and Cruell Turke': The Background of a Renaissance Commonplace, "Studies in the Renaissance", 10 (1963). 
Pocock, J.G.A., El momento maquiavélico. El pensamiento político florentino y la tradición republicana. Madrid, Tecnos, 2002 (1975).

Rousseau, C., "La doctrine de la guerre de Machiavel", en N. Bobbio et al., La guerre et ses théories. París, PUF, 1970, págs. 15-28.

Rummel, E., Erasmus and his catholic critics. I. 1515-1522. II.1523-1536; Nieuwkoop, De Graaf Publishers, 1989, 2 vols.

Russell, F. H., The Just War in the Middle Ages, Cambridge University Press, 1975.

Seidel Menchi, S., Erasmo in Italia, 1520-1580, Torino, Bollati Boringhieri, 1987.

Setton, K. M., Lutheranism and the Turkish peril, "Balkan Studies", III (1962), págs. 133-68.

Skinner, Q., Los fundamentos del pensamiento político moderno. II. La Reforma. México, FCE, 1986 (1978).

Smith, R. O., Luther, the Turks, and Islam, "Currents in Theology and Mission" (oct. 2007), en http://findarticles.com/p/articles/mi m0MDO/ is 5 34/ai n21053788/?tag=content; col1 (Consulta 15.III.2011).

Truyol Serra, A., Prémisses philosophiques et historiques du Totius orbis de Vitoria, “Anuario de la Asoc. F. de Vitoria”, VII (1946-7), págs.. 179201. 